\title{
WNT10A polymorphism may be a risk factor for non-syndromic hypodontia
}

\author{
S.J. Zhang ${ }^{1}$ and Z.Z. Wu ${ }^{2}$ \\ Corresponding author: Z.Z. Wu \\ E-mail: zizhongwu@126.com \\ Genet. Mol. Res. 15 (1): gmr.15016033 \\ Received August 6, 2015 \\ Accepted October 21, 2015 \\ Published March 24, 2016 \\ DOI http://dx.doi.org/10.4238/gmr.15016033
}

1'Department of Stomatology, Qilu Hospital of Shandong University, Jinan, China

${ }^{2}$ Department of Stomatology, The 88th Hospital of PLA, Taian, China

ABSTRACT. This study was designed to determine whether polymorphisms in the gene wingless-type MMTV integration site family, member $10 \mathrm{~A}$ (WNT10A) are associated with non-syndromic hypodontia (tooth agenesis). A case-control study was performed involving 129 subjects with sporadic non-syndromic hypodontia (cases) and 218 healthy individuals (controls). DNA was obtained from whole blood and the ligase detection reaction method was used to analyze two single nucleotide polymorphisms (SNPs) of the WNT10A gene. A significant difference between cases and controls was observed in the allele and genotype frequencies of both SNPs (rs116998555 and rs147680216). For rs116998555, the presence of the T allele (the thymine variant) was associated with tooth agenesis [odds ratio $(\mathrm{OR})=5.722 ; 95 \%$ confidence interval $(\mathrm{Cl})=3.053-10.727 ; \mathrm{P}<0.001]$, while for rs 147680216 , the A allele (the adenine variant) correlated with this condition $(\mathrm{OR}=2.665 ; 95 \% \mathrm{Cl}=1.512-4.695 ; \mathrm{P}<0.001)$. We provide here the first case-control study evidence that risk of hypodontia may be related to the WNT10A polymorphism. Our results also confirm the importance of the Wnt pathway in tooth development.

Key words: Single nucleotide polymorphism; Non-syndromic hypodontia; WNT10A 


\section{INTRODUCTION}

Hypodontia or tooth agenesis is one of the most common human developmental abnormalities and can lead to masticatory dysfunction, speech alteration, esthetic concerns, and malocclusion (Vieira et al., 2004). Tooth agenesis may present as a component of other disorders, such as anhidrotic ectodermal dysplasia, Witkop syndrome, and Rieger syndrome (Kere et al., 1996; Semina et al., 1996; Stimson et al., 1997; Slavkin, 1999). However, the isolated, nonsyndromic form is more common. The prevalence of hypodontia of permanent teeth ranges from 2.2 to $10.1 \%$ in the general population, excluding third molars (Polder et al., 2004).

The literature contains myriad theories regarding the etiology of non-syndromic hypodontia, with many having been suggested prior to the advent of modern genetic studies (Opitz, 2000). Although hypodontia is occasionally caused by environmental factors, in the majority of cases it has a genetic basis (Opitz, 2000). To date, mutations in msh homeobox 1, paired box 9, axin 2, ectodysplasin A, and wingless-type MMTV integration site family, member 10A (WNT10A) have been found to be associated with non-syndromic hypodontia (Vastardis et al., 1996; Mensah et al., 2004; Bergendal et al., 2011; van den Boogaard et al., 2012; Nikopensius et al., 2013). However, many individuals with this condition lack detectable mutations in these five genes and the underlying molecular mechanisms remain unclear.

Dental development, involving many genes and signaling pathways, is a very complex process (Hu and Simmer, 2007). Tooth development requires an array of sequential epithelialmesenchymal interactions involving many signaling molecules, such as growth factors and their receptors, transcription factors, and other modifier proteins (Thesleff and Sharpe, 1997). Alterations in one or more of the genes encoding these signaling molecules may cause tooth agenesis. Gene polymorphism underlies genetic diversity within a species, but there also exists a close relationship between polymorphism and disease susceptibility. Single nucleotide polymorphisms (SNPs), individual nucleotide substitutions that occur at a high frequency in the human genome, are the most common form of genetic variation, capable of affecting gene and protein function (Mostowska et al., 2006), and thus potentially constituting risk factors for non-syndromic hypodontia.

WNT10A mutations have been associated with various ectodermal dysplasia syndromes, ranging from severe autosomal recessive Schopf-Schulz-Passarge syndrome (SSPS) to odontoonycho-dermal dysplasia (OODD) and autosomal dominant missing teeth (Adaimy et al., 2007; Bohring et al., 2009; Nagy et al., 2010). OODD and SSPS share common characteristics, including severe hypodontia. Recent studies have found that mutations in WNT10A are also associated with nonsyndromic hypodontia, for example, Kantaputra and Sripathomsawat (2011) reported that a mutation in this gene gave rise to this condition in an American family, and van den Boogaard et al. (2012) suggested that such mutations are present in more than half of non-syndromic hypodontia cases.

Here, a case-control study was conducted to investigate the association between WNT10A polymorphisms and sporadic non-syndromic hypodontia in the Han Chinese population.

\section{MATERIAL AND METHODS}

\section{Subjects}

We studied 129 sporadic non-syndromic hypodontia patients [56 men and 73 women with a mean age of 25.23 years; standard deviation $(S D)=8.16$ ], and 218 control subjects (103 men and 115 women with a mean age of 32.04 years; SD = 8.16). All individuals participating in 
this study were genetically unrelated ethnic Han Chinese from Shandong or surrounding regions. Sporadic hypodontia patients were diagnosed by clinical examination and dental history, and a standard informed consent form was signed by all subjects. Details of the study population are presented in Table 1.

Table 1. Characteristics of subjects with non-syndromic hypodontia.

\begin{tabular}{l|c}
\hline Subject characteristic & Number (\%) \\
\hline Gender distribution & $56(43.4)$ \\
\hline Men & $73(56.6)$ \\
\hline Women & $52(40.3)$ \\
\hline Number of missing teeth per subject & $40(31.0)$ \\
\hline 1 & $37(28.7)$ \\
\hline 3 or more & $3(1.1)$ \\
\hline Type of teeth missing & $81(30.6)$ \\
\hline Central incisors & $20(7.5)$ \\
\hline Lateral incisors & $33(12.5)$ \\
\hline Canines & $94(35.5)$ \\
\hline First premolars & $9(3.4)$ \\
\hline Second premolars & $25(9.4)$ \\
\hline First molars & 265 \\
\hline Second molars & \\
\hline Total teeth missing & \\
\hline
\end{tabular}

\section{SNP selection}

We identified two SNPs (rs116998555 and rs147680216) that demonstrated greater variation in individuals with hypodontia. As these SNPs can lead to amino acid substitutions in the WNT10A protein, we selected them for genotyping. Details are presented in Table 2.

Table 2. WNT10A single nucleotide polymorphisms (SNPs).

\begin{tabular}{|c|c|c|c|}
\hline SNP site & Alleles & Location in WNT10A & Amino acid substitution \\
\hline \multirow[t]{2}{*}{ rs116998555 } & $\mathrm{C}$ & \multirow[t]{2}{*}{ Exon 3} & \multirow[t]{2}{*}{ Arg $>$ Cys } \\
\hline & $\mathrm{T}$ & & \\
\hline \multirow[t]{2}{*}{ rs147680216 } & G & \multirow[t]{2}{*}{ Exon 3} & \multirow[t]{2}{*}{ Gly $>$ Ser } \\
\hline & $A$ & & \\
\hline
\end{tabular}

\section{DNA extraction}

Genomic DNA was extracted from blood using the TIANamp Blood DNA Midi Kit (Biomed Biotechnologies Inc., Beijing, China), following the manufacturer protocol. DNA integrity and quantity were verified by agarose gel electrophoresis.

\section{Genotyping}

All genotyping experiments were carried out by the Shanghai Biowing Applied Biotechnology Company (Shanghai, China) using the ligase detection reaction (LDR) method. Firstly, target DNA sequences were amplified using multiplex polymerase chain reaction (PCR). Then, samples were incubated with $1 \mu \mathrm{L}$ proteinase $\mathrm{K}(20 \mathrm{mg} / \mathrm{mL})$ at $70^{\circ} \mathrm{C}$ for $10 \mathrm{~min}$ before the reaction was stopped by heating to $94^{\circ} \mathrm{C}$ for $15 \mathrm{~min}$. The ligation reaction for each sample was carried out in a final volume of $20 \mu \mathrm{L}$, containing $20 \mathrm{mM}$ Tris- $\mathrm{HCl}, \mathrm{pH}$ 7.6, $25 \mathrm{mM}$ potassium acetate, $10 \mathrm{mM}$ magnesium acetate, $10 \mathrm{mM}$ dithiothreitol, $1 \mathrm{mM}$ nicotinamide adenine dinucleotide, $0.1 \%$ Triton $\mathrm{X}-100,10 \mu \mathrm{L}$ multiplex 
PCR product, 1 pmol each discriminating probe, 1 pmol each common probe, and $0.5 \mu \mathrm{L}$ Taq DNA ligase (40 U/ $\mu \mathrm{L}$; New England Biolabs, Ipswich, MA, USA). LDRs were performed using 40 cycles of $94^{\circ} \mathrm{C}$ for $30 \mathrm{~s}$ and $63^{\circ} \mathrm{C}$ for $4 \mathrm{~min}$. The fluorescent products were detected using an ABI 377 sequencer (Applied Biosystems, Foster City, CA, USA).

\section{Statistical analysis}

Hardy-Weinberg (HW) equilibrium was tested using the chi-square goodness of fit test to compare observed and expected genotype frequencies for cases and controls. Clinical information and gender was compared across genotypes, using chi-square tests. $P$ values lower than 0.05 were considered statistically significant. Associations between genotypes and risk of sporadic non-syndromic hypodontia were estimated by computing odds ratios (OR) and $95 \%$ confidence intervals $(95 \% \mathrm{Cl})$ from logistic regression analyses. All statistical tests were performed using SPSS 13.0 (SPSS Inc., Chicago, IL, USA).

\section{RESULTS}

For both control and case groups, genotype frequencies were found to be in HW equilibrium $(P>0.05)$.

Both WNT10A SNPs (rs116998555 and rs147680216) exhibited significant differences in allele and genotype frequencies when the case and control groups were compared (Tables 3 and 4). For rs 116998555 , the $C$ allele (the cytosine variant) was identified in $84.1 \%$ of the case group and $97.2 \%$ of the control group, with the T allele (the thymine variant) being found in 15.9 and $2.8 \%$ of each group, respectively $(\mathrm{OR}=5.722 ; 95 \% \mathrm{Cl}=3.053-10.727 ; \mathrm{P}<0.001)$. The rs $116998555 \mathrm{CC}$, $\mathrm{CT}$, and TT genotypes were present at frequencies of $76.0,16.3$, and $7.7 \%$, respectively, in the case group, and $95.0,3.7$, and $1.4 \%$, respectively, in the control group $(P<0.001)$. Thus, for this SNP, the T allele seems to be a risk factor for tooth agenesis.

Table 3. Distribution of alleles in case and control groups.

\begin{tabular}{l|l|c|c|c|c|c|c}
\hline \multirow{2}{*}{ SNP site } & Samples & $\mathrm{N}$ & \multicolumn{2}{|c|}{ Allele N (\%) } & Chi-square & $\mathrm{P}$ & OR (95\%Cl) \\
\hline \multirow{2}{*}{ rs116998555 } & & & $\mathrm{C}$ & $\mathrm{T}$ & & & \\
\cline { 2 - 8 } & Cases & 129 & $217(84.1)$ & $41(15.9)$ & & & \\
\cline { 2 - 8 } & Controls & 218 & $424(97.2)$ & $14(2.8)$ & 35.955 & $<0.001$ & $5.722(3.053-10.727)$ \\
\hline & & & $\mathrm{G}$ & $\mathrm{A}$ & & & \\
\cline { 2 - 8 } & Cases & 129 & $226(87.6)$ & $32(12.4)$ & & & \\
\cline { 2 - 8 } & Controls & 218 & $414(96.0)$ & $22(4.0)$ & 12.227 & $<0.001$ & $2.665(1.512-4.695)$ \\
\hline
\end{tabular}

$\mathrm{OR}=$ odds ratio; $\mathrm{Cl}=$ confidence interval; SNP = single nucleotide polymorphism.

Table 4. Distribution of genotypes in case and control groups.

\begin{tabular}{|c|c|c|c|c|c|c|}
\hline \multirow{3}{*}{$\begin{array}{l}\text { SNP site } \\
\text { rs116998555 }\end{array}$} & Samples & $\mathrm{N}$ & \multicolumn{3}{|c|}{ Genotype N (\%) } & \multirow[t]{2}{*}{$P$} \\
\hline & & & $\mathrm{CC}$ & CT & TT & \\
\hline & Cases & 129 & $98(76.0)$ & $21(16.3)$ & $10(7.7)$ & \\
\hline & Controls & 218 & $208(95.4)$ & $8(3.6)$ & $3(1.4)$ & $<0.001$ \\
\hline \multirow[t]{3}{*}{ rs147680216 } & & & GG & GA & AA & \\
\hline & Cases & 129 & $103(79.8)$ & $20(15.5)$ & $6(4.7)$ & \\
\hline & Controls & 218 & $198(90.8)$ & $18(8.3)$ & $2(0.9)$ & 0.007 \\
\hline
\end{tabular}

SNP $=$ single nucleotide polymorphism . 
Regarding rs 147680216 , the $\mathrm{G}$ allele (the guanine variant) was identified in $87.6 \%$ of the case group and $96.0 \%$ of the control group, while the A allele (the adenine variant) was present in 12.4 and $4.0 \%$ of each group, respectively $(\mathrm{OR}=2.665 ; 95 \% \mathrm{Cl}=1.512-4.695 ; \mathrm{P}<0.001)$. The rs 147680216 GG, GA, and AA genotypes were found at frequencies of $79.8,15.5$, and $4.7 \%$, respectively, in the case group, and $90.8,8.3$, and $0.9 \%$, respectively, in the control group $(P<0.001)$. Therefore, the rs147680216 A allele appears to be associated with increased risk of tooth agenesis.

\section{DISCUSSION}

In this case-control study, we analyzed two SNPs (rs116998555 and rs147680216) in WNT10A in order to investigate their potential roles in tooth agenesis. Our data show that both polymorphisms may be associated with non-syndromic hypodontia. As described above, a number of studies have demonstrated associations between WNT10A mutations and tooth development. Our investigation has further confirmed these findings and has shown that certain WNT10A SNPs may be risk factors in tooth agenesis.

Molecular studies of odontogenesis in mice have demonstrated that a number of Wnt genes are expressed in developing teeth and that changes in their expression may be one of the factors behind tooth agenesis (Zhang et al., 2005). The first evidence for the crucial role of the Wnt pathway in odontogenesis came from a functional analysis of lymphoid enhancer-binding factor 1 (Lef1). The protein product of Lef1 is a transcription factor involved in activating Wnt target genes that also plays a critical role in the survival of epithelial cells during tooth morphogenesis (Sasaki et al., 2005). Lef1null mutant mice die shortly after birth and show abnormalities in epithelial-mesenchymal interactions, which lead to arrest of tooth development at the bud stage (Kratochwil et al., 1996). Defects in odontogenesis are also observed in mice overexpressing Wnt-signaling inhibitors, including Dickkopf and secreted frizzled-related protein 3 (Sarkar and Sharpe, 2000). These studies further support the involvement of Wnt family members, like WNT10A, in tooth agenesis.

Teeth are an important model in the field of evolutionary developmental biology (Line, $2001,2003)$. Teeth are an important model in the field of evolutionary developmental biology. The changes in dental patterning showed that tooth development is very complex. Any change in gene could be associated with changes in the regulation of tooth budding morphogenesis. Polymorphic genetic loci have been directly associated with morphological variation in non-vertebrates. Therefore, it is meaningful to study the association between genetic polymorphism and tooth agenesis (Zimmerman et al., 2000).

Teeth are serially homologous structures, and the effects of gene variations on their development can be quantified easily. Individuals with distinct polymorphic alleles may exhibit subtle and specific phenotypic variations in dental patterning. In this sense, association studies between gene polymorphisms and hypodontia, as well as other mild malformations that reflect qualitative defects in embryogenesis, may aid our understanding of the molecular mechanisms responsible for the subtle phenotypic variations that characterize distinct human populations and ethnic groups (Opitz, 2000).

In this report, we have provided the first case-control study evidence that WNT10A SNPs play a significant role in non-syndromic hypodontia. The importance of the Wnt pathway in tooth development has also been confirmed by these results. However, an understanding of the exact function of WNT10A in odontogenesis requires further detailed analysis of each stage of the process. Future studies involving larger sample sizes and extensive screening of further WNT10A variants, as well as other candidate genes, will be required to determine the true importance of such polymorphisms in human sporadic hypodontia. 


\section{Conflicts of interest}

The authors declare no conflict of interest.

\section{REFERENCES}

Adaimy L, Chouery E, Megarbane H, Mroueh S, et al. (2007). Mutation in WNT10A is associated with an autosomal recessive ectodermal dysplasia: the odonto-onycho-dermal dysplasia. Am. J. Hum. Genet. 81: 821-828.http://dx.doi. org/10.1086/520064

Bergendal B, Klar J, Stecksén-Blicks C, Norderyd J, et al. (2011). Isolated oligodontia associated with mutations in EDARADD, AXIN2, MSX1, and PAX9 genes. Am. J. Med. Genet. A. 155: 1616-1622.http://dx.doi.org/10.1002/ajmg.a.34045

Bohring A, Stamm T, Spaich C, Haase C, et al. (2009). WNT10A mutations are a frequent cause of a broad spectrum of ectodermal dysplasias with sex-biased manifestation pattern in heterozygotes. Am. J. Hum. Genet. 85: 97-105.http:// dx.doi.org/10.1016/j.ajhg.2009.06.001

Hu JC and Simmer JP (2007). Developmental biology and genetics of dental malformations. Orthod. Craniofac. Res. 10: 45-52. http://dx.doi.org/10.1111/j.1601-6343.2007.00384.x

Kantaputra P and Sripathomsawat W (2011). WNT10A and isolated hypodontia. Am. J. Med. Genet. A. 155: 1119-1122.http:// dx.doi.org/10.1002/ajmg.a. 33840

Kere J, Srivastava AK, Montonen O, Zonana J, et al. (1996). X-linked anhidrotic (hypohidrotic) ectodermal dysplasia is caused by mutation in a novel transmembrane protein. Nat. Genet. 13: 409-416.http://dx.doi.org/10.1038/ng0895-409

Kratochwil K, Dull M, Farinas I, Galceran J, et al. (1996). Lef1 expression is activated by BMP-4 and regulates inductive tissue interactions in tooth and hair development. Genes Dev. 10: 1382-1394.http://dx.doi.org/10.1101/gad.10.11.1382

Line SR (2001). Molecular morphogenetic fields in the development of human dentition. J. Theor. Biol. 211: 67-75.http://dx.doi. org/10.1006/jtbi.2001.2333

Line SR (2003). Variation of tooth number in mammalian dentition: connecting genetics, development, and evolution. Evol. Dev. 5: 295-304.http://dx.doi.org/10.1046/j.1525-142X.2003.03036.x

Mensah JK, Ogawa T, Kapadia H, Cavender AC, et al. (2004). Functional analysis of a mutation in PAX9 associated with familial tooth agenesis in humans. J. Biol. Chem. 279: 5924-5933.http://dx.doi.org/10.1074/jbc.M305648200

Mostowska A, Biedziak B and Jagodzinski PP (2006). Axis inhibition protein 2 (AXIN2) polymorphisms may be a risk factor for selective tooth agenesis. J. Hum. Genet. 51: 262-266.http://dx.doi.org/10.1007/s10038-005-0353-6

Nagy N, Wedgeworth E, Hamada T, White JM, et al. (2010). Schöpf-Schulz-Passarge syndrome resulting from a homozygous nonsense mutation in WNT10A. J. Dermatol. Sci. 58: 220-222.http://dx.doi.org/10.1016/j.jdermsci.2010.03.012

Nikopensius T, Annilo T, Jagomägi T, Gilissen C, et al. (2013). Non-syndromic tooth agenesis associated with a nonsense mutation in ectodysplasin-A (EDA). J. Dent. Res. 92: 507-511.http://dx.doi.org/10.1177/0022034513487210

Opitz JM (2000). Heterogeneity and minor anomalies. Am. J. Med. Genet. 92: 373-375.http://dx.doi.org/10.1002/10968628(20000619)92:5<373::AID-AJMG19>3.0.CO;2-Q

Polder BJ, Van't Hof MA, Van der Linden FP and Kuijpers-Jagtman AM (2004). A meta-analysis of the prevalence of dental agenesis of permanent teeth. Community Dent. Oral Epidemiol. 32: 217-226.http://dx.doi.org/10.1111/j.16000528.2004.00158.x

Sarkar L and Sharpe PT (2000). Inhibition of Wnt signaling by exogenous Mfrzb1 protein affects molar tooth size. J. Dent. Res. 79: 920-925.http://dx.doi.org/10.1177/00220345000790040601

Sasaki T, Ito Y, Xu X, Han J, et al. (2005). LEF1 is a critical epithelial survival factor during tooth morphogenesis. Dev. Biol. 278: 130-143.http://dx.doi.org/10.1016/j.ydbio.2004.10.021

Semina EV, Reiter R, Leysens NJ, Alward WL, et al. (1996). Cloning and characterization of a novel bicoid-related homeobox transcription factor gene, RIEG, involved in Rieger syndrome. Nat. Genet. 14: 392-399.http://dx.doi.org/10.1038/ng1296-392

Slavkin HC (1999). Entering the era of molecular dentistry. J. Am. Dent. Assoc. 130: 413-417.http://dx.doi.org/10.14219/jada. archive.1999.0212

Stimson JM, Sivers JE and Hlava GL (1997). Features of oligodontia in three generations. J. Clin. Pediatr. Dent. 21: 269-275.

Thesleff I and Sharpe P (1997). Signalling networks regulating dental development. Mech. Dev. 67: 111-123.http://dx.doi. org/10.1016/S0925-4773(97)00115-9

van den Boogaard MJ, Créton M, Bronkhorst Y, van der Hout A, et al. (2012). Mutations in WNT10A are present in more than half of isolated hypodontia cases. J. Med. Genet. 49: 327-331.http://dx.doi.org/10.1136/jmedgenet-2012-100750

Vastardis H, Karimbux N, Guthua SW, Seidman JG, et al. (1996). A human MSX1 homeodomain missense mutation causes selective tooth agenesis. Nat. Genet. 13: 417-421.http://dx.doi.org/10.1038/ng0896-417 
Vieira AR, Meira R, Modesto A and Murray JC (2004). MSX1, PAX9, and TGFA contribute to tooth agenesis in humans. J. Dent. Res. 83: 723-727.http://dx.doi.org/10.1177/154405910408300913

Zhang YD, Chen Z, Song YQ, Liu C, et al. (2005). Making a tooth: growth factors, transcription factors, and stem cells. Cell Res. 15: 301-316.http://dx.doi.org/10.1038/sj.cr.7290299

Zimmerman E, Palsson A and Gibson G (2000). Quantitative trait loci affecting components of wing shape in Drosophila melanogaster. Genetics 155: 671-683. 